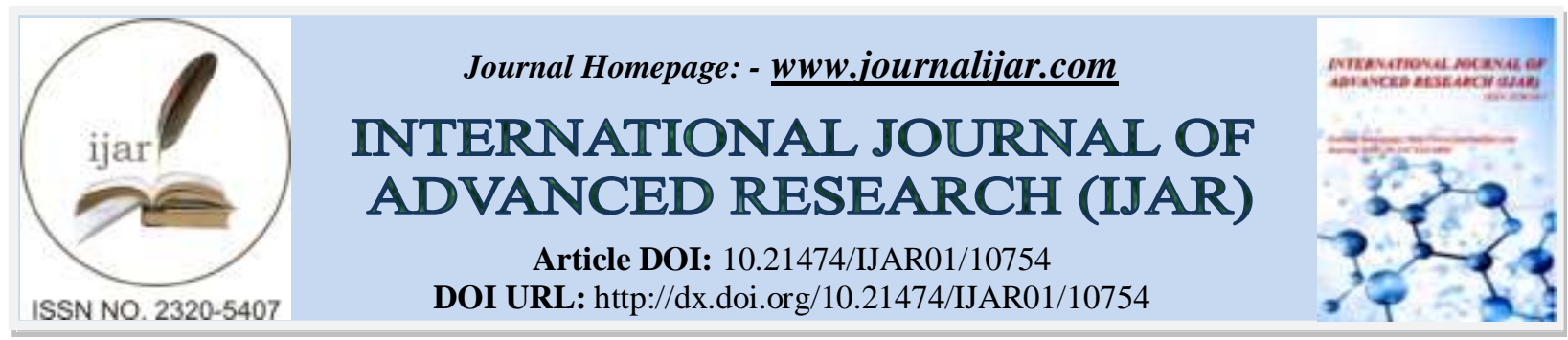

RESEARCH ARTICLE

\title{
A SINGLE CASE STUDY ON ROLE OF AGANTUJ SHALYA (FOREIGN BODY) IN RECURRENCE OF BHAGANDARA I.E. FISTULA IN ANO
}

Dr. Amol Bhaskar Shejwal and Dr. Smita Vinayak Kaloge

Anand Ayurveda College.

\section{Manuscript Info}

Manuscript History

Received: 05 February 2020

Final Accepted: 07 March 2020

Published: April 2020

Key words:-

Bhagandara, Agantuja Shalya, Fistula in Ano

\begin{abstract}
Fistula in anorectal region is an abnormal communication between anal canal and rectum. It is occur due to persistent anal gland infection results in anorectal abscesses which rupture inside as well as outside resulting in fistula.Bhagandara described in ayurveda can be correlated with fistula in ano.The chances of recurrence in different types of anal fistulae range between $7 \%$ to $50 \%$.Foreign body is one of the main reason for recurrence of fistula. Ayurveda text also described Agantuj shalya as a causative factor of Bhagandara. Sushrutacharya described Ksharsutra as an important surgical process for treatment of Bhagandara .A single case study is undertaken to evaluate the examination of presence of foreign body as a causative factor for recurrence of fistula. During surgical procedure foreign body i.e. watermelon seed found in the track of fistula. After removal of this Agantuj shalya and Ksharsutra setting patient showed significant rapid healing and non occurrence of fistula. Hence during surgical process of fistula in ano in each patient examination of fistula tract and its periphery for foreign material is essential.
\end{abstract}

Copy Right, IJAR, 2020,. All rights reserved.

\section{Introduction:-}

Ayurveda classic text described Bhagandara as one of the Ashta Mahagada. ${ }^{[1]}$ Bhagandara is one of the commonest disease which occurs in anorectal region. The literal meaning of Bhagandara is 'Darana'(tearing) in Bhaga i.e. Guda(anal region and perianal space) which means splitting up or piercing up of perianal region. ${ }^{[2]}$ Fistula in ano from modern science can be correlated to Bhagandara described in ayurveda text. ${ }^{[3,4]}$ Fistula in anorectal region is an abnormal communication between anal canal and rectum. It is occur due to persistent anal gland infection results in anorectal abscesses which rupture inside as well as outside resulting in fistula. ${ }^{[5]}$ The chances of recurrence in different types of anal fistulae range between $0.7 \%$ to $37 \%$ in different cases ${ }^{[6]}$ Foreign body is stated as one of the main reason for recurrence of fistula in modern science. ${ }^{[7]}$ Ayurveda text also described Agantuj shalya as a causative factor of Bhagandara. ${ }^{[8]}$ Sushrutacharya described Ksharsutra as an important surgical process in treatment of Bhagandara. ${ }^{[9]}$

Recurrence of fistula is very painful and embarrassing situation for patient because it not only causes physical pain but also affects social and mental harmony of patient. Agantuja shalya (foreign body) is one of the most important cause of recurrence of fistula. In many cases hard particle from food get lodged in the fistula tract during defecation. If such food particles are not get identified during clinical examination or surgical procedure it can 
cause difficulties in healing or recurrence of Bhagandara. ${ }^{[10]}$ Hence while operating fistula surgeon should always check the fistula tract and its periphery for foreign body.

\title{
Case study:
}

A 65 years Male Patient residing in Manmad, Maharashtra came to OPD with chief complaints of recurrent Pain at anal region and discharge through anal region.

\section{Past medical history:}

No history of Hypertension and Diabetes Mellitus

No history of major illness

Past surgical history:

Four time operated for same fistula in ano

$1^{\text {st }}$ time by quack doctor

$2^{\text {nd }}$ time by ayurveda consultant ksharsutra done

$3^{\text {rd }}$ time by General surgeon from modern faculty

Clinical examination:

Pulse: $80 / \mathrm{min}$

Blood pressure : 110/80 mm of hg Respiratory rate -18/min Appetite : Normal

Bowel - Pain during defecation Urine : 5-6 times /day

Sleep : Disturbed due to pain and discharge

Tongue: coated

\section{Ashtvidh Pariksha:}

Nadi : Kaph vataj Mala : Pain during defecation

Mutra : Prakrut Jivha: Saam shabd: Prakrut

Sparsh :Snigdha Aakruti : Madhyam Druk : Prakrut

\section{PR Examination:}

PR was done by using Proctoscope.

Patient had pain during examination. Slight oedema was seen at anal region.

An internal opening was found at cryptoglandular junction 6 O'clock position. External opening at 5 O'clock $2 \mathrm{~cm}$ from anal verge was seen. There is a pus discharge from external opening. All findings were suggestive of Low Anal fistula.

\author{
Pathological investigatigations: \\ $\mathrm{Hb}-13.8 \mathrm{gm} / \mathrm{dl}$ \\ Total WBC $-12,500 /$ cumm \\ Neutrophill-82,Lymphocyts- 35, Monocytes -02, \\ Eosinophills - 01,Basophills- 00 \\ Urine R/M - Normal BT,CT -within normal range, \\ BSL F/PP - Normal ECG -Normal HIV : Negative \\ $\mathrm{HB}_{\mathrm{S}} \mathrm{AG}$ : Negative \\ Physical fitness from physician was granted.
}

\section{Preoperative:}

Shaving and Preparation of operative part was done. IV RL 500ml, IV Monocef (ceftriaxone) 1 gm and IV Pantoprazole 40 were given to patient. Partial Fistulectomy with Ksharsutra was planned.

\section{Surgical Procedure:}

Lithotomy position was given to patient. Savlon betadine painting done.Local anesthesia by Lignocane 2\%was infiltrated around fistula track. A maleable probe B passed from external opening to the internal opening. Partial Fistulectomy with Ksharsutra done .Posterior wall of fistula track was scooped out. While scooping we found extreme fibrous tissue at posterior wall of fistula. That fibrous part was get excised and a foreign body was found. 
The foreign body was watermelon seed. It was removed and dressing was done with Hydrogen peroxide and betadine. Patient shifted to the ward.

\section{Postoperative:}

I.V. DNS 500ml 1point with Inj Tramedol 100mg

I.V Flagyl 100ml

Patient was discharge after 6hrs. Follow up was advised after 2 days. On follow up dressing was done by Jatyadi ghruta. Wound was healthy and healed. Granulation tissue was found. Afterwards patient was advised weekly follow up when Ksharsutra was changed under all aseptic condition .It was repeated again after 7 days. Thus fistula track required three settings of Ksharsutra for healing. Patient was observed for three months and there was no recurrence of fistula.

\section{Observations:-}

Changes observed on various parameters are mentioned below: $\left.{ }^{[11} 12\right]$

\begin{tabular}{|l|l|l|l|l|l|l|}
\hline Sr.NO & $\begin{array}{l}\text { Date of change } \\
\text { of Ksharsutra }\end{array}$ & $\begin{array}{l}\text { Length of } \\
\text { Track }\end{array}$ & Pain & Discharge & Tenderness & Itching \\
\hline 1 & $14 / 12 / 2019$ & $2 \mathrm{~cm}$ & +++ & ++ & +++ & +++ \\
\hline 2 & $21 / 12 / 2019$ & $1 \mathrm{~cm}$ & ++ & + & ++ & ++ \\
\hline 3 & $28 / 12 / 2019$ & Healed & Absent & Absent & Absent & Absent \\
\hline
\end{tabular}

\section{Result:-}

1. In this case recurrence of Bhagandara is four times.

2. After removing of Agantuja shalya i.e.foreign body there is no recurrence of Bhagandara.

3. Total 3 wks or 21 days were required for complete excision and healing of fistula track by Ksharsutra.

\section{Discussion:-}

1. Recurrence is common in Bhagandara Patient.

2. Modern science stated foreign body as a cause of recurrence of fistula in first place. ${ }^{[13]}$ Which suggests importance of examination for foreign body at fistula track.

3. Acharya sushruta also described Shalya as a main causative factor of Bhagandara. ${ }^{[14]}$

4. Bhagandra is a type of Nadivrana. ${ }^{[15]}$ Hence recurrence of Bhagandara can be taken as a 'Arudha Nadivrana' i.e. recurrent and non healing wound. Acharya Vaghbhata stated treatment of Bhagandara like as Vranachikitsa i.e. treatment of wound. ${ }^{[16]}$

5. According to Vaghbhata presence of Shalya ( foreign body) as a main reason for Arudha vrana i.e. Non healing or recurrence of wound. ${ }^{[17]}$ Thus foreign body in fistula track in this case is the main reason for 4 times recurrence of Bhagandara.

6. According to Sushruta symptoms of Sashalya Vrana (wound with foreign body) are Pidkachit (vesicle formation), Shofa (Oedema),Pida(Pain),Mrudumansa (soft granulation tissue formation) and repeated foamy discharge which are present in this patient. ${ }^{[18]}$ This suggests that by observing symptoms clinically one can easily diagnose the presence of Shalya (foreign body) present in Vrana. Because each patient is not affordable to do all radiological investigations to find the foreign body. While working at peripheral level skilled clinical examinations are must.

7. When Shalya (foreign body ) enters in human body if it is not self excreted or treated properly then it get lodged in skin,Mansa(muscular part), arteries, veinsor Srotas (hollow cavities). ${ }^{[19]}$ Thus in this case Shalya i.e. watermelon seed was entered in fistula track through digestive system and it is not self excreted or excised hence get lodge in to fistula track which causes recurrence.

8. Sushruta suggests Bhedan (Incision) and Daran (spilitting) as a treatment for removal of Shalya (foreign body) present in any body part. ${ }^{[20]}$ Kshara have properties of bhedana and lekhana (scrubbing) ${ }^{[21]}$.Hence Ksharasutra can excised the fistula track and help to heal the track by scrubbing the necrose part. 


\section{Conclusion:-}

1. Shalya (foreign body) is a one of the main reason for recurrence of Bhagandara (fistula in ano)

2. Clinical examination are very much important for diagnosis of presence of Shalya(foreign body) in fistula track as every patient can't afford all radiological investigation like MRI.

3. At the end of each surgical procedure for fistula surgeon should have a check for Shalya (foreign body) in fistular track and its periphery.

4. Removal of Shalya(foreign body) can decrease the recurrence of Bhagandara (fistula in ano)

\section{References:-}

1. Shastri Ambikadatta Susruta Samhita Ayurveda Tatvasandipika Hindi Commentary Reprint edition 2014 ,Varanasi ,221001.Chaukhambha Sanskrit Sansthan 33/4

2. Shastri Ambikadatta Susruta Samhita Nidansthan Ayurveda Tatvasandipika Hindi Commentary Reprint edition 2014 ,Varanasi ,221001. Chaukhambha Sanskrit Sansthan ,4/4

3. Dr Rajgopal Shenoy K Manipal manual of surgery second edition 2005 CBS publisher and distributors ,New Delhi,chapter 31

4. Vaidya Yadavji Trikamji Acharya Susruta Samhita Nidansthan Dalhan Sanskrit Commentary Reprint edition 2014 ,Varanasi ,221001.Chaukhambha Sanskrit Sansthan ,4/3

5. Dr Rajgopal Shenoy K Manipal manual of surgery second edition 2005 CBS publisher and distributors ,New Delhi,chapter 31

6. Shrum RC: Anorectal pathology in 1000 consecutive patients with suspected surgical disorders .Dis colon rectum.1959,2:469-472 https://dx.doi.org/10.1007/BF02616939

7. Dr Rajgopal Shenoy K Manipal manual of surgery second edition 2005 CBS publisher and distributors ,New Delhi,chapter 1 /page no 5

8. Vaidya Yadavji Trikamji Acharya Susruta Samhita Nidansthan Dalhan Sanskrit Commentary Reprint edition 2014 ,Varanasi ,221001. Chaukhambha Sanskrit Sansthan ,4/9

9. Vaidya Yadavji Trikamji Acharya Susruta Samhita Chikitsasthan Dalhan Sanskrit Commentary Reprint edition 2014 ,Varanasi ,221001. Chaukhambha Sanskrit Sansthan ,8/4

10. Vaidya Yadavji Trikamji Acharya Susruta Samhita Sutrasthan Dalhan Sanskrit Commentary Reprint edition 2014 ,Varanasi ,221001. Chaukhambha Sanskrit Sansthan26/8-9

11. Dr Rajgopal Shenoy K Manipal manual of surgery second edition 2005 CBS publisher and distributors ,New Delhi,chapter 31 /page no 530-531

12. Vaidya Yadavji Trikamji Acharya Susruta Samhita Nidansthan Dalhan Sanskrit Commentary Reprint edition 2014 ,Varanasi ,221001. Chaukhambha Sanskrit Sansthan ,4/4-9

13. Dr Rajgopal Shenoy K Manipal manual of surgery second edition 2005 CBS publisher and distributors ,New Delhi,chapter 1 /page no 5

14. Vaidya Yadavji Trikamji Acharya Susruta Samhita Nidansthan Dalhan Sanskrit Commentary Reprint edition 2014 ,Varanasi ,221001. Chaukhambha Sanskrit Sansthan ,4/9

15. Vaidya Yadavji Trikamji Acharya Susruta Samhita Nidansthan Dalhan Sanskrit Commentary Reprint edition 2014, Varanasi ,221001. Chaukhambha Sanskrit Sansthan ,10/9-10

16. Late Dr Ganesh Garde Acharya Vagbhata Sarth Vagbhata Uttarsthana eighth edition 1996 Raghuvanshi publication $29 / 43$

17. Late Dr Ganesh Garde Acharya Vagbhata Sarth Vagbhata Uttarsthana eighth edition 1996 Raghuvanshi publication 25/19-20

18. Vaidya Yadavji Trikamji Acharya Susruta Samhita Sutrasthan Dalhan Sanskrit Commentary Reprint edition 2014, Varanasi ,221001. Chaukhambha Sanskrit Sansthan26/9-1 and 2

19. Late Dr Ganesh Garde Acharya Vagbhata Sarth Vagbhata Uttarsthana eighth edition 1996 Raghuvanshi publication 26/19-20

20. Vaidya Yadavji Trikamji Acharya Susruta Samhita Sutrasthan Dalhan Sanskrit Commentary Reprint edition 2014 ,Varanasi ,221001.Chaukhambha Sanskrit Sansthan27/4

21. Late Dr Ganesh Garde Acharya Vagbhata Sarth Vagbhata sutrasthana eighth edition 1996 Raghuvanshi publication 30/1-2. 